\title{
Molecular Characterization of Regionally Endangered Tree Species Mimusops laurifolia (Forssk.) Friis (Sapotaceae)
}

\author{
Sameera O. Bafeel ${ }^{1}$, Abdullah Alaklabi ${ }^{2}$, Ibrahim A. Arif ${ }^{3,4}$, Haseeb A. Khan ${ }^{3,4}$, Ahmad H. Alfarhan ${ }^{3}$, Anis \\ Ahamed $^{3,4}$, Jacob Thomas ${ }^{3}$ \& Mohammad A. Bakir ${ }^{3,4}$ \\ ${ }^{1}$ Department of Biology, King Abdulaziz University (KAU), Jeddah, Saudi Arabia \\ ${ }^{2}$ Department of Biology, Al-Baha University (BU), Baljurashi, Saudi Arabia \\ ${ }^{3}$ Department of Botany \& Microbiology, King Saud University (KSU), Riyadh, Saudi Arabia \\ ${ }^{4}$ Molecular Fingerprinting \& Biodiversity Unit, College of Science, King Saud University, Riyadh, Saudi Arabia \\ Correspondence: Mohammad A. Bakir, Department of Botany \& Microbiology, Building Number 5, College of \\ Science, King Saud University (KSU), Riyadh, Saudi Arabia. Tel: 966-1467-5837. E-mail: mbakir@ksu.edu.sa
}

Received: April 16, 2012 Accepted: May 9, 2012 Online Published: June 7, 2012

doi:10.5539/ijb.v4n3p29 URL: http://dx.doi.org/10.5539/ijb.v4n3p29

\begin{abstract}
Mimusops laurifolia (Forssk.) Friis is the largest tree species in the Arabian Peninsula and a characteristic species of the threatened 100 individuals that currently remained only at eleven localities. We determined the rbcL (ribulose-1, 5-bisphosphate carboxylase/oxygenase large subunit) gene sequence, current phylogenetic status and RAPD (Random Amplification of Polymorphic DNA) fingerprinting pattern of this regionally endangered plant species. Overall rbcL gene sequence similarity among the 18 plant species under the family Sapotaceae was very high (99.8\%). The plastid rbcL gene sequence of $M$. laurifolia was identical to that of $M$. zeyheri indicating that $M$. laurifolia and M. zeyheri are very closely related plant species. M. laurifolia also showed close phylogenetic relation with Argania spinosa (99.6\%). The RAPD profiles of M. laurifolia generated amplified products ranging from 517 to $1664 \mathrm{bp}$. A total of 11 bands were observed for M. laurifolia for 3 RAPD-primers. Morphological taxonomy of M. laurifolia and it's differential characters with similar plant species M. zeyheri are also briefly discussed in this study.
\end{abstract}

Keywords: Mimusops laurifolia, rbcL, RAPD

\section{Introduction}

Mimusops laurifolia (Forssk) Friis, (Synonym, Binectaria laurifolia Forssk., M. schimperi A. Rich.; Sapotaceae) (Friis, 1980) is the largest tree species in the Arabian Peninsula. It is native to Yemen, Saudi Arabia, Ethiopia and Somalia (Friis, 1980; Friis, 1992). Recently, this plant regained popularity since the extract was patented for skin-conditioning and moisturizing effects as part of preparations used in cosmetics, bath formulations and detergents (Ohara et al., 2001). The seeds are known to produce nine kinds of saponins (Eskander et al., 2006). M. laurifolia is a characteristic species of the threatened 100 individuals that are known to remain only at eleven localities. Many of these are extremely old trees with little or no regeneration. Attempts to multiply this slow growing tree have been so far failed (Kilan et al., 2004). Recently, these conditions are such a rarity in southwest Arabia that any future new records of $M$. laurifolia are likely to be of isolated adult tree which may not regenerate anymore. M. laurifolia was classified as endangered in the region on the IUCN red list (Hall et al., 2010). M. laurifolia is very less studied plant species. Plastid rbcL is the most commonly sequenced gene for phylogenetic studies of plants (Schuettpelz et al., 2006) and RAPD provides very quick and easy molecular characterization of taxa with some limitations (Penner et al., 1993). In this study, we determined the rbcLgene sequence based phylogenetic status and RAPD fingerprinting profile of this regionally endangered plant species. Descriptions of morphological characters of M. laurifolia are also briefly discussed in this study.

\section{Materials and Methods}

This study comprised of a specimen (specimen 4, voucher KSU 21544; Figure 3) taken from a tree in Al-Baha, Saudi Arabia (19.8653679, 41.3029594). The leaf samples were individually placed in plastic pouches and transported to the laboratory where the specimen was stored at $-80^{\circ} \mathrm{C}$, until processed for DNA extraction. The plant was identified on the basis of morphological characters by Dr. Jacob Thomas, Curator, Herbarium, KSU. The 
leaf specimen was immersed in liquid nitrogen and crushed using sterile mortar and pestle to get fine powder. DNeasy plant mini kit (Qiagen) and an automated DNA extraction instrument (QIAcube, Qiagen) were used for DNA isolation. Quality of the extracted DNA was determined using gel electrophoresis and Nanodrop 8000 Spectrophotometer (Thermo Scientific, Wilmington, USA). Isolated plant genomic DNA was preserved at $-80^{\circ} \mathrm{C}$. Primer pair R1 (rbcLaF, 5'ATGTCACCACAAACAGAGACTAAAGC3' (Levin, 2003); rbcLaR 5'GTAAAATCAAGTCCACCRCG3' (Kress and Erickson, 2007) and R2 (rbcL1F, 5ATGTCACCACAAACAGAAAC3 (Fay et al., 1997); rbcL724R, 5'TCGCATGTACCTGCAGTAGC3' (Fay et al., 1997) were used in this study for the amplification of rbcL gene of the chloroplast region. A total volume of 30 $\mu \mathrm{L}$ of PCR reaction mixture contained the following: $15 \mu \mathrm{L}$ of FideliTaq PCR Master Mix \{(USB Corporation, Cleveland, $\mathrm{OH}$ ), giving a final concentration of $200 \mu \mathrm{M}$ each deoxynucleotide and $\left.1.5 \mathrm{mM} \mathrm{MgCl}_{2}\right\}, 1 \mu \mathrm{M}$ each primer (Eurofins MWG Operon, Germany), $2 \mu \mathrm{L}$ of genomic DNA and the rest adjusted with sterile distilled water. PCR amplification was performed with a Veriti 96 well thermal cycler (Applied Biosystems) as follows: $95^{\circ} \mathrm{C}$ for $1 \mathrm{~min}$, followed by 35 cycles of $95^{\circ} \mathrm{C}$ for $30 \mathrm{~s}, \mathrm{~T}^{\circ} \mathrm{C}\left(51^{\circ} \mathrm{C}\right.$ for the primer pair R1 and $48^{\circ} \mathrm{C}$ for the primer pair R2) for $30 \mathrm{~s}$ and $68^{\circ} \mathrm{C}$ for $1 \mathrm{~min}$, followed by an elongation step at $68^{\circ} \mathrm{C}$ for $5 \mathrm{~min}$. A long $(20 \times 14 \mathrm{~cm}) 1 \%$ agarose gel using $1 \mathrm{x}$ TAE buffer containing $0.5 \mu \mathrm{g} / \mathrm{mL}$ ethidium bromide was used for electrophoresis of PCR-products. Gel images were obtained using Proxima C16 Phi+ (Isogen Life Science) UV transilluminator and Opticom (version 3.2.5; OptiGo) imaging system. The amplified PCR products were determined on gel for the presence or absence of the band. The size of PCR products resulting from the primer pairs were determined by using an Amersham 100-bp ladder (GE Healthcare) and the TotalLab TL100 1D software (version 2008.01). Sequences were determined directly using the dideoxynucleotide chain-termination method with DNA-sequencer (ABI PRISM 3130xl; Applied Biosystems/Hitachi) and BigDye Terminator version 3.1 cycle sequencing RR-100 kit (Applied Biosystems), according to the manufacturer's instructions. Sequences were submitted to DDBJ/EMBL/GenBank database (Accession no. 4R1, JQ304270; 4R2, JQ304271). BLAST (Basic Local Alignment Search Tool) and BOLD (The Barcode of Life Data Systems) searches were applied to the produced sequences using the available online databases. Sequences of $\mathrm{rbcL}$ that were matched with the query sequences were retrieved from GenBank database. The sequences were aligned using CLUSTAL X (version 1.81) (Thompson et al., 1997). Phylogenetic analyses were conducted in MEGA5 (Tamura et al., 2007). Phylogenetic trees were constructed using Maximum Parsimony (MP, Close-Neighbor-Interchange algorithm; Nei and Kumar, 2000), Maximum Likelihood (ML; Tamura \& Nei, 1993) and Neighbor-Joining (NJ; Saitou \& Nei, 1987) methods. The topologies of the phylogenetic trees were evaluated by using the bootstrap resampling method (Felsenstein, 1985) with 1000 replicates.

Ready-To-Go RAPD analysis beads (GE Healthcare, Buckinghamshire, UK) were used for RAPD-PCR analysis. The PCR mixture of $25 \mu \mathrm{L}$ contained a single Ready-To-Go RAPD analysis bead, 25 pmol of a single RAPD primer, $50 \mathrm{ng}$ of template DNA and sterile distilled water. The bead contained thermo-stable polymerase (AmpliTaq ${ }^{\mathrm{TM}}$ DNA polymerase and Stoffel fragment), dNTPs $(0.4 \mathrm{mM}$ each), BSA $(2.5 \mu \mathrm{g})$ and buffer $(3 \mathrm{mM}$ $\mathrm{MgCl}_{2}, 30 \mathrm{mM} \mathrm{KCl}$ and $10 \mathrm{mM}$ Tris, $\mathrm{pH}$ 8.3). Three primers (P1, P3 \& P6; GE Healthcare, UK) were used in this study. Each primer is a 10-mer of arbitrary sequence: P1 (5'-GGTGCGGGAA-3'), P3 (5'-GTAGACCCGT-3') and P6 (5'CCCGTCAGCA-3'). PCR was performed using a Veriti 96-well thermal cycler (Applied Biosystems, USA). PCR conditions included 1 cycle of $95^{\circ} \mathrm{C}$ for $5 \mathrm{~min}$, followed by 45 cycles of $95^{\circ} \mathrm{C}$ for $1 \mathrm{~min}, 36^{\circ} \mathrm{C}$ for $1 \mathrm{~min}$ and $72^{\circ} \mathrm{C}$ for $2 \mathrm{~min}$. A long $(20 \times 14 \mathrm{~cm}) 1 \%$ agarose gel using $1 \mathrm{X}$ TAE buffer containing $0.5 \mu \mathrm{g} / \mathrm{mL}$ ethidium bromide was used for electrophoresis of the products. Gel images were obtained using Proxima C16 Phi+ (Isogen Life Science) UV transilluminator and Opticom (version 3.2.5; OptiGo) imaging system. Gel image analysis of the RAPD bands obtained for the plant species using different RAPD primers was performed using an Amersham 100-bp ladder (GE Healthcare) and the TotalLab TL100 1D software (version 2008.01).

\section{Results}

We obtained about 648 (4R1) and 814 bp (4R2) of PCR products of the rbcL gene of the plastid region of the species M. laurifolia using two sets of primer. Database search was conducted using the produced sequences. BLAST search with 4R1 showed the specimen (M. laurifolia) is identical (100\% sequence similarity) to $M$. zeyheri. Search with 4R2 showed very close relationship ( $99 \%$ sequence similarities) with multiple plant species (Argania spinosa, EU980805; Monotheca buxifolia, AF421097; Pouteria reticulata, GQ428632). Recently developed BOLD identification system search of 4R1 showed 100\% sequence similarities with multiple plant species under the genus Mimusops (M. caffra, M. obovata, M. commersoni and M. zeyheri). BOLD search with 4R2 showed 99.6\% sequence similarities with Argania spinosa and Monotheca buxifolia. All the plant species that showed high level of sequence similarities $(>99 \%)$ in the database search (genBank and BOLD) were included in the tree analyses. In general, all the inferred trees (MP, ML and NJ) showed similar topology. 
According to all the tree analyses $M$. laurifolia was identical to that of $M$. zeyheri indicating that $M$. laurifolia and $M$. zeyheri are closely related plant species. M. laurifolia also showed close phylogenetic relation with Argania spinosa however, demonstrated a separate lineage from A. spinosa (supported by $80 \%, 65 \%$ and $67 \%$ of bootstrap values for MP, ML and NJ trees, respectively) (Figure 1; Supplementary Figures $1 \& 2$ ). Pair-wise sequence similarities of M. laurifolia were $100 \%$ with M. zeyheri and $99.6 \%$ with $A$. spinosa (Table 1). Overall average sequence similarity was observed very high (99.8\%) among 18 plant species under the family Sapotaceae that were included in the tree analyses. All the rbcL gene sequence based phylogenetic trees demonstrated that different plant species under the family Sapotaceae are very closely related except Diploon cuspidatum and Pradosia ptychandra (Figure 1; Supplementary Figures 1 \& 2).

Table 1. Estimates of pair-wise rbcL gene sequence similarities (\%) among the studied taxa

\begin{tabular}{|c|c|c|c|c|c|c|c|c|c|c|c|c|c|c|c|c|c|c|}
\hline No. & 1 & 2 & 3 & 4 & 5 & 6 & 7 & 8 & 9 & 10 & 11 & 12 & 13 & 14 & 15 & 16 & 17 & 18 \\
\hline 2 & 99.6 & & & & & & & & & & & & & & & & & \\
\hline 3 & 100 & 99.6 & & & & & & & & & & & & & & & & \\
\hline 4 & 100 & 99.6 & 100 & & & & & & & & & & & & & & & \\
\hline 5 & 99.6 & 100 & 99.6 & 99.6 & & & & & & & & & & & & & & \\
\hline 6 & 99.4 & 99.8 & 99.4 & 99.4 & 99.8 & & & & & & & & & & & & & \\
\hline 7 & 99.6 & 100 & 99.6 & 99.6 & 100 & 99.8 & & & & & & & & & & & & \\
\hline 8 & 99.6 & 100 & 99.6 & 99.6 & 100 & 99.8 & 100 & & & & & & & & & & & \\
\hline 9 & 99.6 & 100 & 99.6 & 99.6 & 100 & 99.8 & 100 & 100 & & & & & & & & & & \\
\hline 10 & 99.6 & 100 & 99.6 & 99.6 & 100 & 99.8 & 100 & 100 & 100 & & & & & & & & & \\
\hline 11 & 99.6 & 100 & 99.6 & 99.6 & 100 & 99.8 & 100 & 100 & 100 & 100 & & & & & & & & \\
\hline 12 & 99.6 & 100 & 99.6 & 99.6 & 100 & 99.8 & 100 & 100 & 100 & 100 & 100 & & & & & & & \\
\hline 13 & 99.4 & 99.8 & 99.4 & 99.4 & 99.8 & 99.6 & 99.8 & 99.8 & 99.8 & 99.8 & 99.8 & 99.8 & & & & & & \\
\hline 14 & 99.6 & 100 & 99.6 & 99.6 & 100 & 99.8 & 100 & 100 & 100 & 100 & 100 & 100 & 99.8 & & & & & \\
\hline 15 & 99.6 & 99.6 & 99.6 & 99.6 & 99.6 & 99.4 & 99.6 & 99.6 & 99.6 & 99.6 & 99.6 & 99.6 & 99.4 & 99.6 & & & & \\
\hline 16 & 99.6 & 100 & 99.6 & 99.6 & 100 & 99.8 & 100 & 100 & 100 & 100 & 100 & 100 & 99.8 & 100 & 99.6 & & & \\
\hline 17 & 99.6 & 100 & 99.6 & 99.6 & 100 & 99.8 & 100 & 100 & 100 & 100 & 100 & 100 & 99.8 & 100 & 99.6 & 100 & & \\
\hline 18 & 99.6 & 100 & 99.6 & 99.6 & 100 & 99.8 & 100 & 100 & 100 & 100 & 100 & 100 & 99.8 & 100 & 99.6 & 100 & 100 & \\
\hline 19 & 99.6 & 100 & 99.6 & 99.6 & 100 & 99.8 & 100 & 100 & 100 & 100 & 100 & 100 & 99.8 & 100 & 99.6 & 100 & 100 & 100 \\
\hline
\end{tabular}

1. Mimusops laurifolia specimen 4R1, 2. Manilkara zapota, 3. Mimusops laurifolia specimen 4R2, 4. Mimusops zeyheri, 5. Manilkara huberi, 6. Diploon cuspidatum, 7. Micropholis cayennensis, 8. Pouteria singularis, 9. Pouteria gongrijpii, 10. Chrysophyllum sanguinolentum, 11. Pouteria reticulate, 12. Manilkara bidentata, 13. Pradosia ptychandra, 14. Pouteria filipes, 15. Argania spinosa, 16. Monotheca buxifolia, 17. Sideroxylon inerme, 18. Madhuca microphylla, 19. Palaquium formosanum. Identical sequence similarities $(100 \%)$ were typed in bold. 


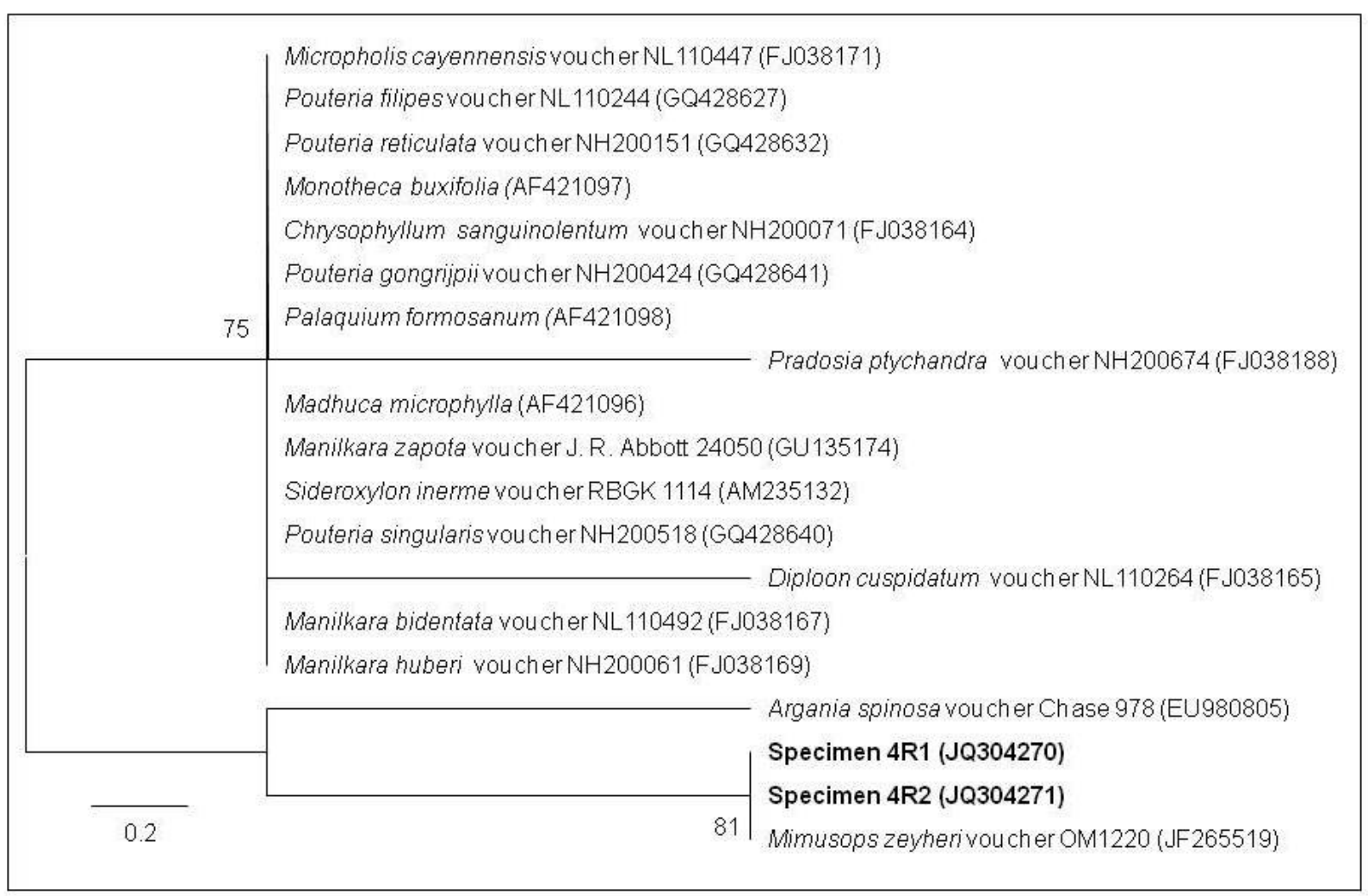

Figure 1. Maximum Parsimony tree inferred from the rbcL gene sequences of the studied specimens, Mimusops laurifolia and related taxa

The bootstrap consensus tree inferred from 1000 replicates is taken to represent the evolutionary history of the taxa analyzed. The scale represents the units of the number of changes over the whole sequence. GenBank accession numbers are written in parentheses.

The RAPD banding pattern of the endangered plant species M. laurifolia is illustrated in Figure 2. The RAPD profiles using the sample generated amplified products ranging from 517 to $1664 \mathrm{bp}$. A total of 11 bands were observed for the plant species using 3 primers. The number of major bands for the plant species for a single primer ranged from 3 to 5 . The maximum number of major bands was observed for the primer P6 (5 bands) and the equal number of bands for P1 and P3 (3 bands, Figure 2).
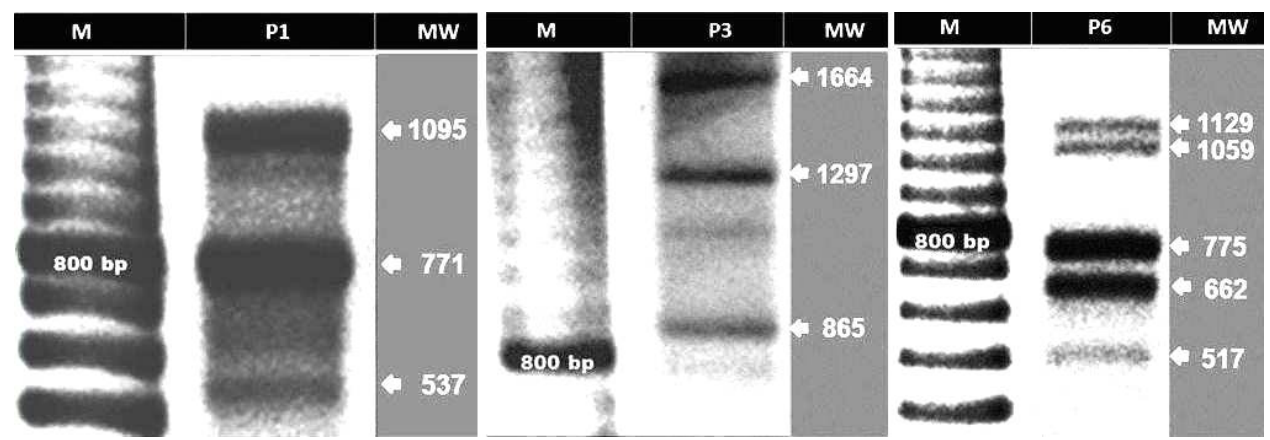

Figure 2. RAPD-PCR product profile of the regionally endangered plant M. laurifolia. M, 100-bp molecular weight marker; P, Ready-To-Go RAPD analysis primers (P1, P3 \& P6; GE Healthcare, Buckinghamshire, UK); MW, Molecular weight 


\section{Discussion}

M. laurifolia showed very close relationship with M. zeyheri based on the rbcL gene sequence phylogeny. Morphologically $M$. laurifolia is closely related with $M$. zeyheri and previously this species was classified as a variety of M. zeyheri (M. zeyheri var. laurifolia; Engler, 1904). Literature on the description of taxonomy of $M$. laurifolia is very scarce and typified with a single specimen found in the Forsskäl herbarium (Friis, 1980). Mimusops laurifolia (Forssk.) Friis and M. zeyheri (Sond.) are extremely similar morphologically (Figures 3 \& 4) with notable few differences that are illustrated in Table 2.

Table 2. Morphological comparison of M. lurifolia and M. zeyheri

\begin{tabular}{|c|c|c|}
\hline Characters & M. laurifolia & M. zeyheri \\
\hline $\begin{array}{l}\text { Color of tender } \\
\text { branches }\end{array}$ & Brown or green & Pink or crimson \\
\hline Tree trunk & Buttresses present & Buttresses absent \\
\hline Pubescence & Young braches glabrous or thinly pubescent & $\begin{array}{l}\text { Young branches densely pubescent, } \\
\text { covered with light reddish colored } \\
\text { hairs }\end{array}$ \\
\hline Petiole & $\begin{array}{l}\text { Petiole of mature leaves } 4-5 \mathrm{~cm} \text { long and } \\
\text { young leaves } 3-4 \mathrm{~cm} \text { long }\end{array}$ & petiole $0 \cdot 6-3 \cdot 5 \mathrm{~cm}$ long \\
\hline Pedicel (in flower) & $1-2.5 \mathrm{~cm}$ long & $1-1.7 \mathrm{~cm}$ long \\
\hline Style & $1.5-2.5 \mathrm{~mm}$ long & 5-9 mm long \\
\hline Distribution & $\begin{array}{l}\text { Southwestern Arabian Peninsula and north } \\
\text { eastern Africa }\end{array}$ & Angola-South Africa and Tanzania \\
\hline
\end{tabular}
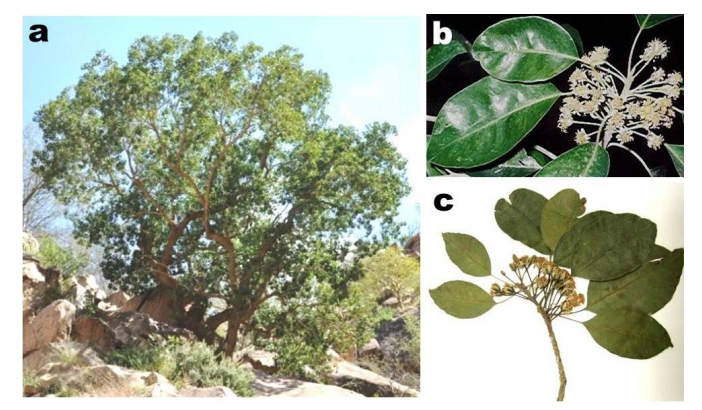

Figure 3. a. M. laurifolia tree; b. Leaf and flower; c. Herbarium specimen of Mimusops laurifolia (KSU 21544)

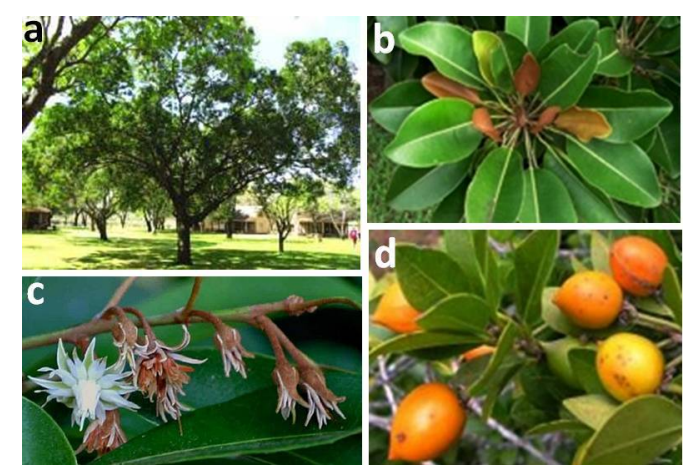

Figure 4. a. Mimusops zeyheri tree; b. Leaf; c. Flower; d. Fruit. Adapted from Lemmens (2005); Land plants (2007); The African Expedition Magazine (2012) 
M. zeyheri is distributed in the area of Tanzania to South Africa (Bisby et al., 2011). M. laurifolia is distributed in south western wadis and lower heights of Saudi Arabia, tropical East Africa and Yemen (Chaudhary, 1999). Species-descriptions of M. laurifolia include it as a high, large-trunked tree and grow up to $30 \mathrm{~m}$ tall. Leaves are usually crowded towards the ends of branches; petiole can be observed up to $4 \mathrm{~cm}$ long; lamina broadly elliptical $( \pm 9 \times 4.5 \mathrm{~cm})$, entire obtuse. Flowers are solitary axillary, long pedicelled; pedical can be up to $20 \mathrm{~mm}$. Sepals densely tomentose; outer sepal usually $7 \mathrm{~mm}$ long, inner sepal a little smaller. Petals are $\pm 9 \mathrm{~mm}$ long. Fruits are oval yellowish green in color, berry $(4 \times 2.5 \mathrm{~cm})$, edible and sweetish (Chaudhary, 1999). Plastid rbcL is the most commonly sequenced gene for phylogenetic studies of plants (Schuettpelz et al., 2006) because of the other plant marker such as matK is difficult to amplify and sequence (Bafeel et al., 2011; Hollingsworth, 2011). Previous study based on rbcL gene sequence showed that Glycyrrhiza uralensis was identical to that of G. inflata, indicating that G. uralensis and G. inflata are closely related species (Hayashi et al., 2000). RAPD primers are able to characterize taxa (Choo et al., 2009) because RAPD analysis includes both of the coding and non-coding regions of the genome (Vanijajiva et al., 2005). However, some of the reported problems with RAPD are related to reproducibility, designing appropriate primers and amplification of RAPD-PCR products. PCR conditions constitute another crucial factor for obtaining amplified products, especially for plants (Jones et al., 1997). It is suggested that if the overall temperature profiles (annealing temperature) inside the PCR tubes are identical, RAPD fragments are then likely to be reproducible (Penner et al., 1993; Skroch \& Nienhuis, 1995).

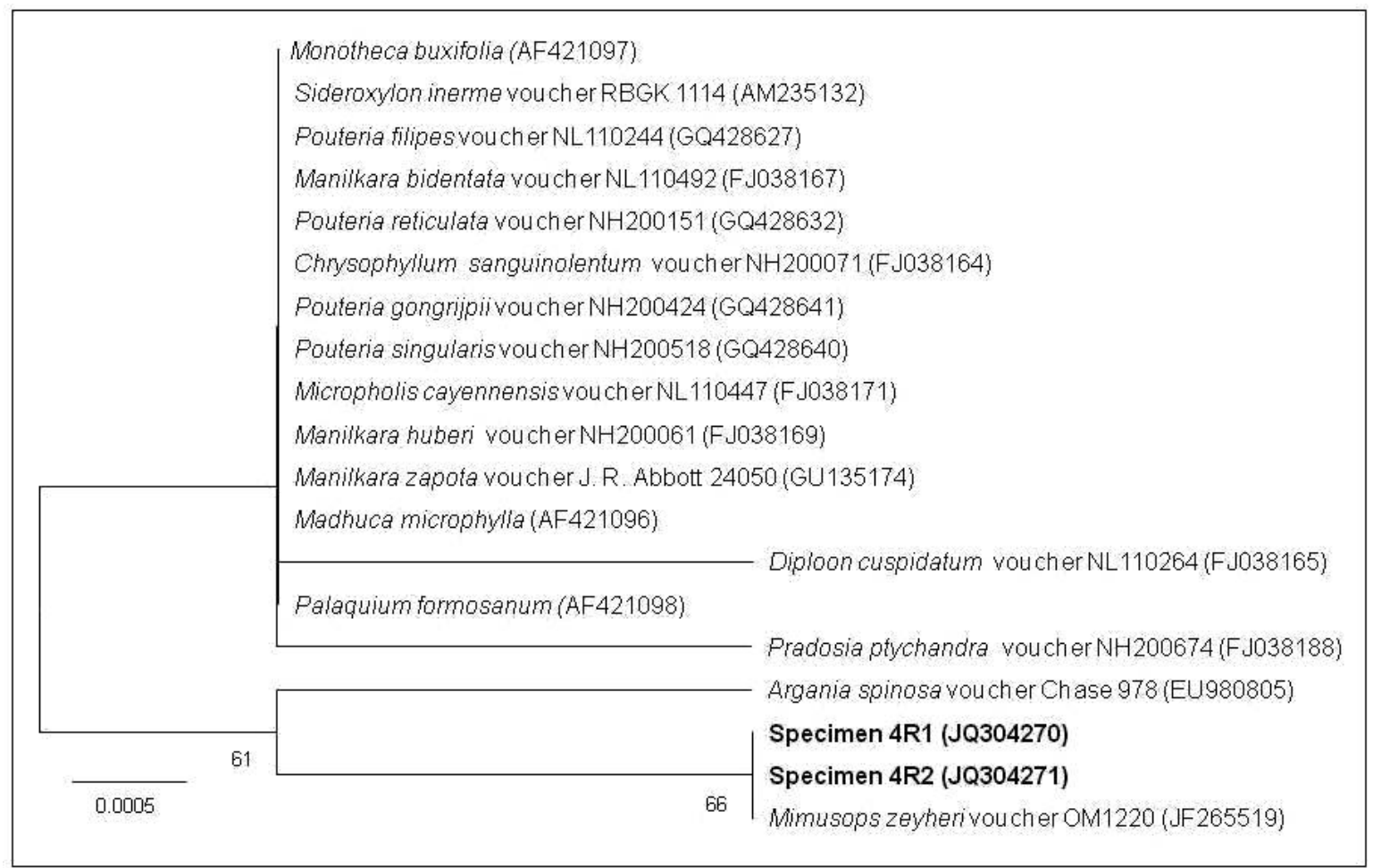

Supplementary Figure 1. Maximum Likelihood tree inferred from the rbcL gene sequences of the studied specimens and the related taxa

The bootstrap consensus tree inferred from 1000 replicates is taken to represent the evolutionary history of the taxa analyzed. The scale represents the units of the number of changes over the whole sequence. GenBank accession numbers are written in parentheses. 


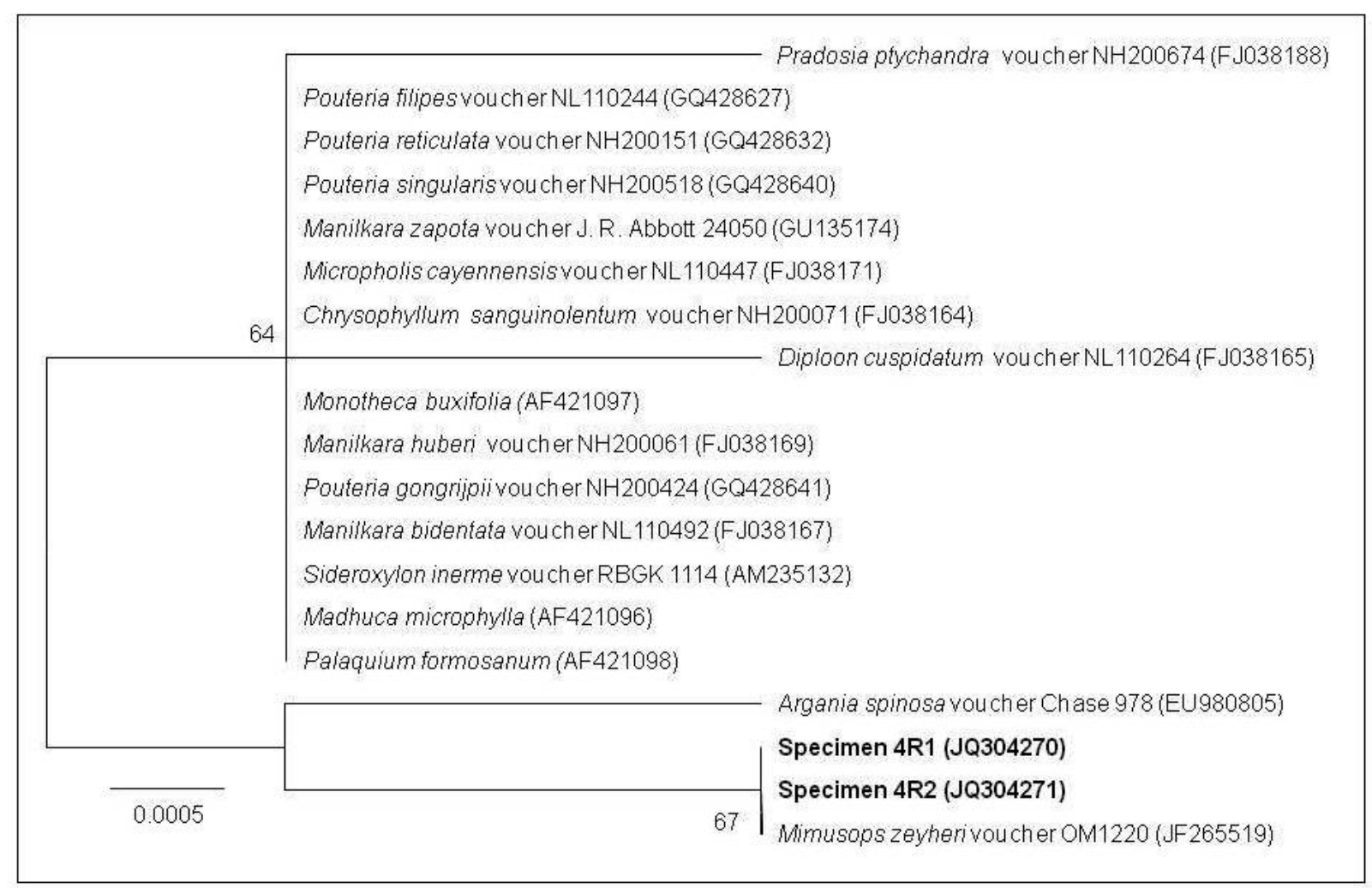

Supplementary Figure 2. Neighbor-Joining tree inferred from the rbcL gene sequences of the related taxa with the studied specimen

The bootstrap consensus tree inferred from 1000 replicates is taken to represent the evolutionary history of the taxa analyzed. The scale represents the units of the number of changes over the whole sequence. GenBank accession numbers are written in parentheses

\section{Conclusions}

Plastid rbcL gene based phylogeny showed M. laurifolia is very closely related with $M$. zeyheri and very close relationship among the other morphologically defined taxa under the family Sapotaceae. Development of markers with high discriminatory power at species level is necessary to clarify the phylogenetic status of the different plant species under the family Sapotaceae.

\section{Acknowledgements}

Supports from the Deanship of Scientific Research, College of Science Research Center, King Saud University are duly acknowledged.

\section{References}

Bafeel, S. O., Arif, I. A., Bakir, M. A., Khan, H. A., Farhan, A. H. A., Homaidan, A. A. A., Ahamed, A., \& Thomas, J. (2011). Comparative evaluation of PCR success with universal primers of maturase K (matK) and ribulose-1, 5-bisphosphate carboxylase/oxygenase large subunit $(\mathrm{rbcL})$ for barcoding of some arid plants. Plant Omics Journal, 4, 195-198. Available: http://www.pomics.com/khan_4_4_2011_195_198.pdf

Bisby, F. A., Roskov, Y. R., Orrell, T. M., Nicolson, D., Paglinawan, L. E., Bailly, N., Appeltans, W., Kirk, P. M., Bourgoin, T., Baillargeon, G., \& Ouvrard, D. (2011). Species 2000 \& ITIS Catalogue of Life. Reading, UK: Species 2000. [Online] Available: http://www.catalogueoflife.org/col/

Chaudhary, S. A. (1999). Sapotaceae. In Chaudhary, S. A. (Ed.). Flora of the Kingdom of Saudi Arabia Illustrated. (Vol. 1, pp. 546-549). Riyadh: Ministry of Agriculture and Water, National Herbarium, National Agriculture and Water Research Center.

Choo, B. K., Moon, B. C., Ji, Y., Kim, B. B., Choi, G., Yoon, T., \& Kim, H. K. (2009). Development of SCAR markers for the discrimination of three species of medicinal plants, Angelica decursiva (Peucedanum 
decursivum), Peucedanum praeruptorum and Anthricus sylvestris, based on the internal transcribed spacer (ITS) sequence and random amplified polymorphic DNA (RAPD). Biological \& Pharmaceutical Bulletin, 32, 24-30. http://dx.doi.org/10.1248/bpb.32.24

Engler, A. (1904). Monographien Afrikanischer pflanzen familien und gattungen, 8, 73.

Eskander, J., Lavaud, C., Pouny, I., Soliman, H. S. M., Khalik, S. M. A., \& Mahmoud, I. I. (2006). Saponins from the seeds of Mimusops laurifolia. Phytochemistry, 67, 1793-1799. http://dx.doi.org/10.1016/j.phytochem.2005.11.008

Fay, M. F., Swensen, S. M., \& Chase, M. W. (1997). Taxonomic affinities of Medusagyne oppositifolia (Medusagynaceae). Kew Bulletin, 52, 111-120. http://dx.doi.org/10.2307/4117844

Felsenstein, J. (1985). Confidence limits on phylogenies: an approach using the bootstrap. Evolution, 39, 783-791. http://dx.doi.org/10.2307/2408678

Friis, I. (1980). The taxonomy and distribution of Mimusops laurifolia (Sapotaceae). Kew Bulletin, 35, 785-795. http://dx.doi.org/10.2307/4110174

Friis, I. (1992). Forests and forest trees of Northeast tropical Africa. Kew Bulletin Additional Series, 15.

Hall, M., Neale, S., Al-Abbasi, T. M., \& Miller, A. G. (2010). Arabia's tallest trees: ecology, distribution and conservation status of the regionally endangered tree species Mimusops laurifolia. Nordic Journal of Botany, 28, 240-245. http://dx.doi.org/10.1111/j.1756-1051.2009.00560.x

Hayashi, H., Hosono, N., Kondo, M., Hiraoka, N., Ikeshiro, Y., Shibano, M., Kusano, G., Yamamoto, H., Tanaka, T., \& Inoue, K. (2000). Phylogenetic relationship of six Glycyrrhiza species based on rbcL sequences and chemical constituents. Biological \& Pharmaceutical Bulletin, 23, 602-6. http://dx.doi.org/10.1248/bpb.23.602

Hollingsworth, P. M. (2011). Refining the DNA barcode for land plants. Proceedings of the National Academy of Sciences USA, 108, (49), 19451-19452. http://dx.doi.org/10.1073/pnas.1116812108

Jones, C. J., Edwards, K. J., Castaglione, S., Winfield, M. O., Sala, F., van de Wiel, C., Bredemeijer, G., Vosman, B., Matthes, M., Daly, A. et al. (1997). Reproducibility testing of RAPD, AFLP and SSR markers in plants by a network of European laboratories. Molecular Breedeing, 3, 381-390. http://dx.doi.org/10.1023/A:1009612517139

Kilian, N., Hein, P., \& Hubaishan, M. A. (2004). Further notes on the flora of the southern coastalmountains of Yemen. Willdenowia, 34, 159-182. http://dx.doi.org/10.3372/wi.34.34114

Kress, J., \& Erickson, D. L. (2007). A two-locus global DNA barcode for land plants: the coding $r b c L$ gene complements the non-coding trnH-psbA spacer region. PLoS One, 2(6), e508. http://dx.doi.org/10.1371/journal.pone.0000508

Land plants. (2007). Mimusops zeyheri. Available: http://www.landplants.ru/encikloped/6190/

Lemmens, R. H. M. J. (2005). Mimusops zeyheri Sond. Prota 7(1), Timbers/Bois d'œuvre 1. [CD-Rom]. In Louppe, D., Amoako, O. A. A., \& Brink, M. (Eds), Wageningen, Netherlands: PROTA. Available: http://database.prota.org/PROTAhtml/Mimusops\%20zeyheri_En.htm

Levin, R. A., Wagner, W. L., Hoch, P. C., Nepokroeff, M., Pires, J. C., Zimmer, E. A., \& Sytsma, K. J. (2003). Family-level relationships of Onagraceae based on chloroplast rbcL and ndhF data. American Journal of Botany, 90, 107-115. http://dx.doi.org/10.3732/ajb.90.1.107

Nei, M., \& Kumar, S. (2000). Molecular Evolution and Phylogenetics. New York, USA: Oxford University Press.

Ohara, M., Doi, M., \& Kondo, M. (2001). Cosmetics, bath preparations and detergents containing moisturizing extracts of Sapotaceae plants. Japanese Kokai Tokkyo Koho JP. 200122732.

Penner, G. A., Bush, A., Wise, R., Kim, W., Domier, L., Kasha, K., Laroche, A., Scoles, G., Molnar, S. J., \& Fedak, G. (1993). Reproducibility of random amplified polymorphic DNA (RAPD) analysis among laboratories. Genome Research, 2, 341-345. http://dx.doi.org/10.1101/gr.2.4.341

Saitou, N., \& Nei, M. (1987). The neighbor-joining method: A new method for reconstructing phylogenetic trees. Molecular Biology \& Evolution, 4, 406-425. Available: http://mbe.oxfordjournals.org/content/4/4/406.full.pdf + html

Schuettpelz, E., Korall, P., \& Pryer, K. M. (2006). Plastid atpA data provide improved support for deep relationships among ferns. Taxon, 55, 897-906. http://dx.doi.org/10.2307/25065684

Skroch, P., \& Nienhuis, J. (1995). Impact of scoring error and reproducibility of RAPD data on RAPD based estimates of genetic distance. Theoretical \& Applied Genetics, 91, 1086-1091. http://dx.doi.org/10.1007/BF00223923 
Tamura, K., \& Nei, M. (1993). Estimation of the number of nucleotide substitutions in the control region of mitochondrial DNA in humans and chimpanzees. Molecular Biology \& Evolution, 10, 512-526. Available: http://mbe.oxfordjournals.org/content/10/3/512.full.pdf + html

Tamura, K., Dudley, J., Nei, M., \& Kumar, S. (2007). MEGA4: Molecular Evolutionary Genetics Analysis (MEGA) software version 4.0. Molecular Biology \& Evolution, 24, 1596-1599. http://dx.doi.org/10.1093/molbev/msm092

The African Expedition Magazine. (2012). Transvaal red milkwood - Mimusops zeyheri. Available: http://africanxmag.com/bush_food.htm

Thompson, J. D., Gibson, T. J., Plewniak, F., Jeanmougin, F., \& Higgins, D. G. (1997). The CLUSTAL X windows interface: flexible strategies for multiple sequence alignment aided by quality analysis tools. Nucleic Acids Research, 24, 4876-4882. http://dx.doi.org/10.1093/nar/25.24.4876

Vanijajiva, O., Sirirugsa, P., \& Suvachittanont, W. (2005). Confirmation of relationships among Boesenbergia (Zingiberaceae) and related genera by RAPD. Biochemical Systematics \& Ecology, 33, 159-170. http://dx.doi.org/10.1016/j.bbr.2011.03.031 